\title{
PELATIHAN KESIAPSIAGAAN BENCANA PADA SISWA SD MELALUI PERMAINAN EDUKATIF "AKSANA"
}

\section{DISASTER PREPAREDNESS FOR STUDENT OF ELEMENTARY SCHOOL THROUGH EDUCATIVE GAMES “AKSANA"}

\author{
Oleh: \\ Yessy Elita, Rita Sinthia, Mona Ardina \\ Fakultas Keguruan dan Ilmu Pendidikan, Universitas Bengkulu \\ Email: yessyelita@unib.ac.id
}

\begin{abstract}
Bengkulu Province is an area located on three tectonic plates namely Indo-Australia, Eurasia, and Pacific which contain potential natural disasters such as earthquakes and tsunamis. Therefore, it is very important to prepare the community to be prepared for the disaster, including children. In every event of a disaster, there are many victims of children. Providing of knowledge and skills will minimize loss of life. Considering the importance of disaster preparedness, disaster preparedness training activities are carried out through educative games "AKSANA". The word of AKSANA means Anak Sadar Bencana. This disaster preparedness training was attended by 30 students of SDN I Kota Bengkulu. School selection based on high level of disaster potential. SDN I is surrounded by beaches and is in the lowlands with a distance of less than $1 \mathrm{~km}$ from the beach. The service method is through AKSANA games consisting of disaster ladder snake, crosswords, and playbook about a disaster. In this activity, it was equipped with a simulation of selfrescue during an earthquake at the school accompanied by the PMI of Bengkulu Province. The effectiveness of disaster preparedness training in elementary school children was indicated by a significant increase in the pre-test and post-test scores from the average category (6.4) to high (8.9). With the increase in test scores, it shows that disaster preparedness training through AKSANA games can improve the knowledge and skills of students of SDN 1 Kota Bengkulu in dealing with natural disasters.
\end{abstract}

Keywords: Disaster, preparedness, children

\section{PENDAHULUAN}

Provinsi Bengkulu merupakan wilayah yang berpotensi bencana alam karena posisinya yang terletak dalam lintasan lempeng tektonik Indo-Australia, lempeng Eurasia, dan lempang pasifik. Pada setiap kejadian bencana, baik bencana alam maupun man made disaster, jumlah anak-anak yang menjadi korban sangat besar. Data yang tercatat pada tahun 2005, sebanyak 1.962 infastruktur pendidikan rusak berat, akibat gempa bumi dan tsunami di Indonesia. Sebanyak 45.000 siswa dan 1.870 guru dilaporkan hilang dan meninggal dunia, $42 \%$ dari populasi yang meninggal adalah anak-anak di bawah usia 12 tahun (Beringin, 2011). Besarnya korban jiwa dari sisi anak-anak disebabkan karena ketidakmampuan mereka melindungi diri saat terjadinya bencana. Ketidakmampuan anak 
dalam melindungi diri dikarenakan kurangnya pengetahuan dan keterampilan anak pada saat menghadapi bencana. Dengan alasan tersebut, maka sangat mendesak dilaksanakan kegiatan pelatihan kesiapsiagaan bencana pada anak SD. Kegiatan pengabdian masyarakat berupa pelatihan kesiapsiagaan bencana dengan menggunakan permainan edukatif sebagai sarana pembelajaran. Permainan edukatif ini diberi nama AKSANA yang merupakan singkatan Anak Sadar Bencana.

Pelaksanaan kegiatan bertempat di SDN I Kota Bengkulu yang terletak di Jalan Prof. Dr. Hazairin Kelurahan Malabero Kecamatan Teluk Segara. Dari letak geografis, SDN 1 berada dalam zona yang rawan terjadi bencana gempa bumi dan tsunami karena terletak sangat dekat dari pantai (kurang dari $1 \mathrm{~km}$ ) dan berada di dataran yang rendah. Kesadaran akan potensi ancaman bencana alam yang dapat terjadi pada siswa SDN I telah tertuang dalam visi sekolah yaitu membentuk siswa yang tanggap bencana melalui pendidikan dan pengembangan budaya siaga bencana. Sayangnya, kegiatan pelatihan kesiapsiagaan jarang dilakukan. Berdasarkan wawancara dari relawan PMI Provinsi Bengkulu terakhir dilaksanakan kegiatan kesiapsiagaan bencana pada tahun 2009 oleh pihak PMI sendiri. Pengakuan siswa kelas VB, mereka pernah melaksanakan kegiatan tersebut lima tahun yang lalu. Padahal idealnya, simulasi penyelamatan diri saat bencana dilakukan secara berkala.

Pembelajaran mengenai kebencanaan kepada anak harus memperhatikan tahap perkembangan kognitif siswa Sekolah Dasar dan juga karakteristik anak. Pada usia SD, yaitu 7-12 tahun, anak berada dalam tahap perkembangan kognitif operasional konkret (Piaget dalam Ormrod, 2009). Anak-anak telah dapat melakukan penalaran deduktif, sehingga mampu menarik kesimpulan-kesimpulan logis berdasarkan informasi yang diberikan kepada mereka. Namun, anak-anak masih kesulitan dalam memahami gagasangagasan yang abstrak, sehingga pembelajaran yang tepat bagi anak menggunakan media belajar atau alat peraga yang dapat diamati langsung. Selain memperhatikan tahap perkembangan kognitif anak SD, dunia anak-anak adalah dunia bermain. Bermain merupakan suatu aktivitas yang menyenangkan, karena itu akan lebih mudah bagi anak untuk menyerap berbagai informasi yang baru dengan sikap positif dan tanpa paksaan (Sugianto dalam Hildayani dkk, 2007). Tahap bermain anak usia 8 sampai11 tahun adalah kegiatan bermain sosial. Kegiatan bermain ini dilakukan bersama dengan anak-anak lain dengan melibatkan aturan permainan. Jenis permainan "meja" (board games) seperti ular tangga, halma, monopoli sesuai untuk anak usia tersebut.

Permainan edukatif dipilih sebagai sarana belajar mengenai kebencanaan karena dunia anak-anak tidak lepas dari dunia bermain. Melalui bermain, anak akan belajar mengenai banyak hal dan dapat meningkatkan berbagai macam keterampilan baik dari aspek fisik, motorik, kognitif, sosial serta emosi (Smith, 1995 dalam Hildayani, 2007). Konsep dan prosedur dari materi pendidikan pengurangan risiko bencana melibatkan motivasi dalam diri siswa dan menciptakan pembelajaran bermakna dalam diri siswa sehingga pembelajaran dapat bertahan lama dalam memori jangka panjang (Johnson et all, 2014).

Pada kegiatan pelatihan kesiapsiagaan bencana pada anak SD selain menggunakan permainan edukatif sebagai sarana pembelajaran, juga memberikan simulasi kebencanaan pada anak. Mereka dikondisikan seolah-olah berada dalam situasi gempa bumi dan diajarkan teknik-teknik untuk menyelamatkan diri. Dengan melibatkan dua metode baik melalui permainan dan simulasi diprediksikan bahwa pemerolehan pengetahuan mengenai kebencanaan pada anak lebih optimal. 
Kegiatan PPM berbasis IPTEKS ini bertujuan untuk meningkatkan kesiapsiagaan bencana pada anak melalui permainan edukatif yaitu permainan ular tangga, teka teki silang dan buku bermain AKSANA. Ketiga permainan ini kemudian disebut dengan permainan AKSANA (Anak Sadar Bencana). Melalui permainan ini, pengetahuan dan keterampilan anak mengenai kebencanaan meningkat sehingga apabila terjadi bencana diharapkan mereka dapat melindungi diri. Satu hal yang tidak kalah penting adalah anakanak Sekolah Dasar yang dilibatkan dalam Pelatihan Kesiapsiagaan Bencana ini dapat menjadi agen berbagi pengetahuan kebencanaan kepada teman sebaya, keluarga dan masyarakat di mana mereka tinggal.

\section{METODE PENGABDIAN}

Kegiatan ini dimulai dengan melakukan kunjungan ke SDN I pada tanggal 1 Mei 2018 untuk menjalin kemitraan dengan SDN I Kota Bengkulu yang beralamat di Jalan Prof. Dr. Hazairin, Kelurahan Malabero, Kecamatan Teluk Segara, Kota Bengkulu. Kedatangan tim pengabdian masyarakat ini disambut dengan baik oleh Kepala Sekolah SDN I Kota Bengkulu. Pada pertemuan ini, Kepala Sekolah menunjukkan antusiasme dan kesadaran yang sangat besar akan pentingnya pelatihan kesiapsiagaan bencana ini. Pelaksanaan kegiatan dijadwalkan pada tanggal 10 dan 11 Agustus 2018 dengan melibatkan siswa kelas V B sebanyak 30 anak sebagai peserta pelatihan kesiapsiagaan bencana.

Selain melakukan kemitraan dengan pihak SDN I Kota Bengkulu, kegiatan Pengabdian ini juga menjalin kemitraan dengan pihak PMI Provinsi Bengkulu. Pihak PMI menyambut baik tujuan kegiatan Pelatihan Kesiapsiagaan Bencana pada Anak SD merupakan bentuk kegiatan pengabdian masyarakat yang harus dilakukan untuk mengedukasi masyarakat. Pihak PMI sebagai tenaga ahli yang kompeten untuk memberikan kegiatan simulasi penyelamatan diri saat terjadi gempa bumi di sekolah.

Metode pelatihan kesiapsiagaan bencana menggunakan permainan-permainan edukatif yang disebut permainan AKSANA (Anak Sadar Bencana) terdiri dari permainan ular tangga, teka teki silang dan buku bermain. Pada kegiatan pelatihan kebencanaan ini dilengkapi dengan simulasi penyelamatan diri saat terjadi gempa bumi di sekolah. Lebih lanjut mengenai metode permainan dijelaskan sebagai berikut.

1. Ular tangga AKSANA

Permainan ini dibuat dengan menggunakan prinsip permainan ular tangga. Perbedaan dengan ular tangga biasa adalah Ular Tangga AKSANA memiliki tema kebencanaan dan tema lokasi Kota Bengkulu. Permainan ini diadaptasi dari permainan Ular Tangga yang dimiliki oleh Muhammadiyah Disaster Management Centre, Kemitraan Indonesia Australia, dan Klub Siaga Bencana Kota Padang. Permainan dibuat dalam dua ukuran yaitu ukuran A3 yang dapat dimainkan di meja dan ukuran besar yaitu 3 x 2 meter yang dapat dimainkan di lapangan sekolah. Permainan ini dapat dimainkan oleh $2-4$ orang anak. Cara bermain dengan melemparkan dadu dan menggerakkan pion sesuai dengan angka dadu yang keluar. Perbedaan dengan permainan ular tangga pada umumnya, yaitu pada petak-petak tertentu yaitu petak hijau (peluang), petak merah (risiko) dan petak kuning. Terdapat pertanyaan-pertanyaan yang harus dijawab. Pertanyaan ini mengenai pengetahuan kebencanaan dan simulasi kebencanaan. Pemenang dalam permainan ini adalah yang telah mencapai garis finish. 


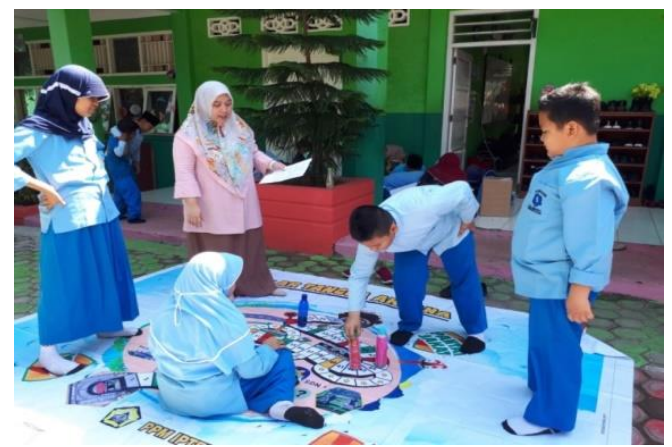

Gambar 1. Bermain Ular Tangga Aksana di lapangan

Pada gambar 1 siswa berjumlah 4 orang sedang bermain ular tangga Aksana berukuran besar. Permainan dilakukan di lapangan atau tempat terbuka. Sementara pada gambar 2, bermain ular tangga dilakukan di meja belajar. Permainan ular tangga menjadi permainan yang seru dan juga meningkatkan pengetahuan mengenai kebencanaan.

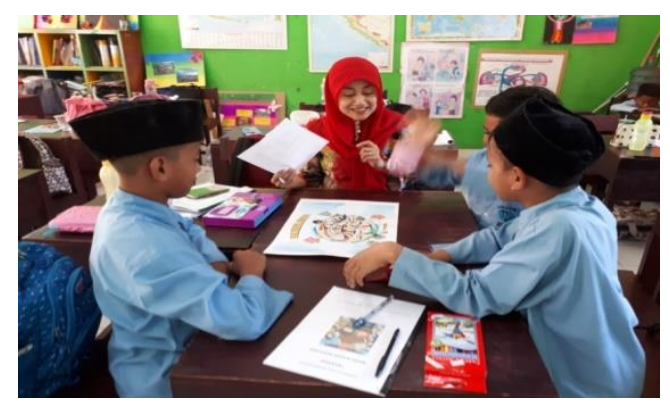

Gambar 2. Bermain ular tangga di meja

\section{Buku Permainan AKS ANA}

Buku ini adalah buku mengenai pengetahuan kebencanaan yang dikemas dalam bentuk permainan-permainan. Buku ini merupakan bentuk modifikasi dari buku permainan kebencanaan yang berjudul Ready Wrigley for Earthquake dari U.S Departement of Health and Human Services dan juga menggunakan sumber buku panduan menghadapi bencana di sekolah "Sahabat Siaga" (UNDP DRR A Project, 2011). Permainan-permainan yang ada dalam buku ini antara lain: memecahkan kode rahasia, mencari kata, temukan benda dengan mewarnai, dan mencari perbedaan gambar. Selain permainan, juga diselingi dengan pengetahuan-pengetahuan penting mengenai cara melindungi diri dalam situasi bencana yaitu gempa bumi, banjir, tanah longsor, kebakaran dan tsunami yang sangat mungkin terjadi di Kota Bengkulu. 


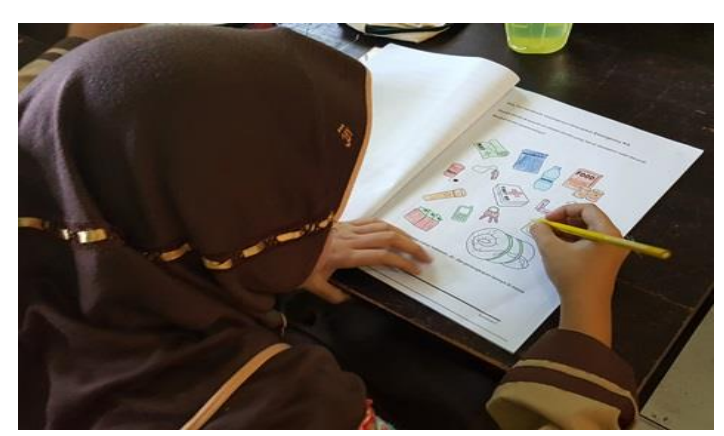

Gambar 3. Mengerjakan Buku Aksana

\section{Teka-teki silang AKSANA}

Permainan ini menggunakan prinsip bermain teka teki silang yang mengisi kata-kata baik secara mendatar dan menurun. Pertanyaan-pertanyaan yang ada dalam TTS AKSANA ini berupa pengetahuan kebencanaan baik pengetahuan umum, dan pengetahuan praktis mengenai cara melindungi diri. TTS in terdiri dari 20 pertanyaan yang dikerjakan secara mendatar dan menurun. TTS ini dibuat dalam ukuran 1,5 x 1,5 meter, sehingga dapat dikerjakan di depan kelas. Permainan ini dibuat seperti kompetisi dan anak-anak berlomba-lomba untuk menjawab. Bentuk TTS dapat dilihat pada gambar 4.

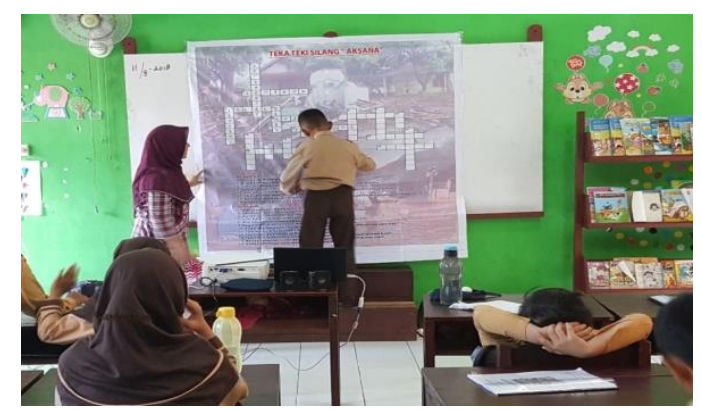

Gambar 4. Bermain TTS Aksana

Permainan-permainan ini telah melalui proses pengujian para ahli untuk melihat kesesuaian permainan dengan sasaran yang dikehendaki, mengetahui bagaimana tingkat pemahaman anak terhadap permainan, dan bahasa yang digunakan dalam permainan.

4. Simulasi penyelamatan diri saat gempa bumi

Setelah kegiatan bermain dengan permainan AKSANA, pelatihan ini diakhiri dengan simulasi kebencanaan di sekolah. Simulasi dilaksanakan di hari kedua kegiatan pelatihan, yaitu pada tanggal 11 Agustus 2018. Dengan adanya simulasi anak dapat mempraktikkan pengetahuan yang telah diperoleh baik dari permainan ular tangga, TTS, buku bermain dan dari film yang diputarkan. Kegiatan simulasi melibatkan tenaga ahli dari PMI. Pada simulasi ini, anak-anak diajarkan melindungi diri saat terjadi gempa di dalam kelas dan di luar kelas. Selain itu pada simulasi ini, pihak PMI memberikan pembekalan pada pimpinan sekolah, guru, perawat UKS, pihak keamanan, dan mahasiswa agar dapat mengarahkan siswa dan memberikan pertolongan saat terjadi bencana. Kegiatan ini diikuti berbagai pihak dengan antusias dan sungguh-sungguh. 

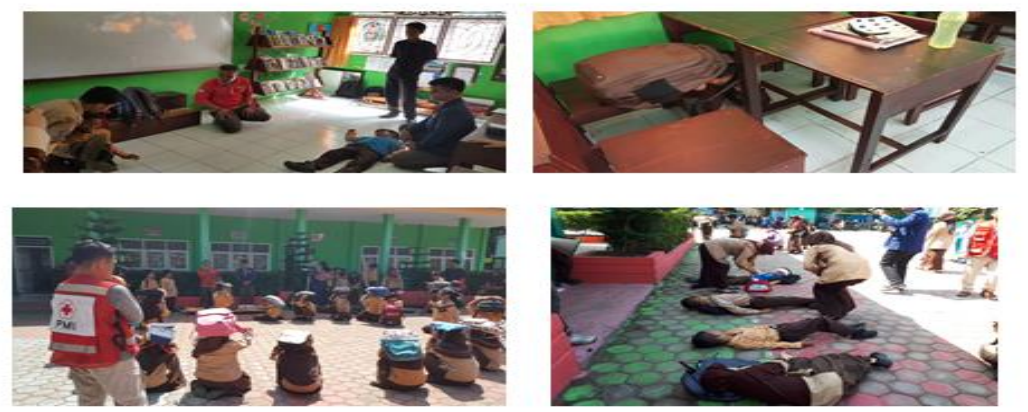

Gambar 5. Kegiatan simulasi bencana di SDN I Kota Bengkulu

\section{Alat Pengumpul Data}

Untuk melihat efektivitas pelatihan kesiapsiagaan bencana pada siswa maka sebelumnya dilakukan pre test dan post tes mengenai pengetahuan kebencanaan. Tes ini terdiri dari 25 soal dengan 2 model pertanyaan yaitu pilihan Benar dan Salah serta memilih pilihan ganda. Indikator dalam pre test yaitu: pengetahuan mengenai kondisi wilayah, pengetahuan kebencanaan (gempa, tsunami, banjir, kebakaran, tanah longsor) dan teknik penyelamatan diri saat bencana.

\section{HASIL DAN PEMBAHASAN}

Kegiatan Pelatihan Kesiapsiagaan bencana melalui permainan AKSANA dilaksanakan pada tanggal 10 dan 11 Agustus 2018 dengan berjalan sukses dan diikuti dengan antusias oleh siswa kelas VB dan juga berbagai pihak yaitu Pimpinan Sekolah, Guru, Penjaga keamanan, dan mahasiswa. Kegiatan pada hari pertama yaitu mengajak siswa bermain sambil belajar melalui permainan yang terdiri dari ular tangga aksana, Buku Bermain, dan TTS Aksana. Untuk memaksimalkan pengetahuan anak mengenai kebencanaan juga diputarkan video mengenai bencana gempa bumi dan tsunami. Sementara, kegiatan pada hari kedua yaitu simulasi penyelamatan diri saat terjadi gempa bumi di sekolah. Simulasi ini melibatkan tenaga ahli dari PMI.

Pihak PMI merancang skenario simulasi gempa bumi saat proses belajar sedang berlangsung. Siswa diberikan keterampilan untuk dapat melindungi diri sesuai dengan SOP yaitu: melindungi kepala dengan tas, berlindung di bawah meja, menjauhi kaca-kaca, dan berkumpul di lapangan. Pada kegiatan ini, siswa sangat antusias dan dapat mempraktikkannya dengan baik. Selain itu, pada kegiatan simulasi ini, sikap mental siswa juga dibentuk agar dapat bersikap tenang meskipun dalam situasi darurat.

Keberhasilan kegiatan pelatihan kesiapsiagaan bencana melalui permainan AKSANA ditunjukkan dengan meningkatnya skor saat pre test yang rata-rata kelas memiliki skor 64 (sedang) dan meningkat secara signifikan dengan rata-rata kelas menjadi 89. Lebih lanjut mengenai skor pre dan post tes dapat dilihat pada tabel 1 .

Tabel 1. Nilai Pre Test

\begin{tabular}{cccc}
\hline Range Nilai & Frekwensi & Persentase & Kategori \\
\hline $80-100$ & 2 & 6,9 & Tinggi \\
$60-79$ & 18 & 62 & Sedang \\
$40-59$ & 9 & 31 & Rendah \\
\hline Total & $\mathbf{2 9}$ & $\mathbf{1 0 0}$ & \\
\hline Rerata Nilai & $\mathbf{6 4}$ & & Sedang \\
\hline
\end{tabular}


Berdasarkan tabel 1 mayoritas siswa memiliki pengetahuan mengenai kebencanaan yang tergolong sedang sebanyak $62 \%$ dan rendah sebanyak $31 \%$. Hanya sebanyak 2 orang siswa yang memiliki pengetahuan tinggi. Hal ini menunjukkan bahwa perlunya pelatihan kesiapsiagaan bencana untuk dapat meningkatkan pengetahuan dan kesiapsiagaan bencana pada anak SD. Setelah diberikan perlakuan dalam bentuk permainan AKSANA dan simulasi penyelamatan diri saat bencana. Nilai siswa mengalami peningkatan yang signifikan dari 64 menjadi 89. Lebih detil dapat dilihat pada tabel 2.

Tabel 2. Nilai Post Test

\begin{tabular}{lccc}
\hline \multicolumn{1}{c}{ Range Nilai } & Frekwensi & Persentase & Kategori \\
\hline $80-100$ & 26 & 93 & Tinggi \\
$60-79$ & 2 & 7 & Sedang \\
$40-59$ & - & - & \\
\hline Total & $\mathbf{2 8}$ & $\mathbf{1 0 0}$ & \\
\hline Rerata Nilai & $\mathbf{8 9}$ & & Tinggi \\
\hline
\end{tabular}

Peningkatan nilai rerata saat pre test sebesar 64 dalam kategori sedang meningkat menjadi 89 dalam kategori tinggi. Dari rerata menunjukkan bahwa pelatihan kesiapsiagaan bencana melalui permainan AKSANA dapat meningkatkan pengetahuan dan kesiapsiagaan bencana pada anak SD. Permainan AKSANA ini adalah sarana belajar melalui permainan. Perkembangan kognitif anak siswa SD kelas V yang berusia 10 dan 11 tahun berada dalam tahap perkembangan kognitif operasional konkret sehingga proses belajar mengajar pada anak yang terbaik adalah melalui media pembelajaran yang menarik perhatian anak. Media pembelajaran dalam kegiatan pelatihan ini melalui permainan yaitu ular tangga AKSANA, TTS, dan Buku bermain dan Belajar AKSANA.

Bermain dan permainan adalah dunia anak-anak. Melalui permainan ini anak memperoleh pengetahuan dalam suasana yang menyenangkan. Selain itu, kegiatan pelatihan ini menerapkan prinsip learning by doing, sehingga dengan mempraktikkan atau mensimulasikan cara penyelamatan diri saat bencana maka akan lebih membekas dalam memori jangka panjang. Akan tetapi, pengetahuan yang masuk dalam memori apabila tidak mengalami pengulangan, maka akan terlupakan.

Keberlanjutan kegiatan pelatihan kesiapsiagaan bencana pada anak SD menjadi hal yang sangat penting. Pihak sekolah melalui guru diharapkan dapat meneruskan pengetahuan mengenai kebencanaan pada siswa-siswa lainnya mengingat Kota Bengkulu adalah daerah yang rawan bencana alam khususnya gempa bumi dan tsunami. Dengan membekali siswa dengan pengetahuan mengenai kebencanaan dan keterampilan penyelamatan diri, maka diharapkan dapat meminimalkan risiko akibat bencana.

\section{KESIMPULAN DAN SARAN}

\section{Kesimpulan}

Kegiatan pelatihan kesiapsiagaan bencana melalui permainan AKSANA dapat disimpulkan berhasil dengan baik dan tepat sasaran serta mendapatkan dukungan dari pihak sekolah baik dari kepala sekolah, guru-guru, mahasiswa Bimbingan dan Konseling, dan pihak PMI Provinsi Bengkulu. Berdasarkan hasil pre test dan post test yang diikuti oleh 30 anak menunjukkan peningkatan pengetahuan kebencanaan dari skor rata-rata 64 menjadi skor rata-rata 89 (tinggi). Kegiatan pelatihan kesiapsiagaan yang menggunakan 
beberapa jenis permainan yaitu ular tangga, teka teki silang dan buku bermain AKSANA. Disamping permainan, juga diputarkan video mengenai gempa bumi dan tsunami. Puncak dari kegiatan ini, adalah simulasi kebencanaan, khususnya bencana gempa bumi saat proses belajar di dalam kelas. Dengan simulasi, maka proses pembelajaran mengenai kebencanaan akan terekam dengan baik di memori jangka panjang siswa. Kegiatan pelatihan kebencanaan ini berlangsung dengan lancar dan diikuti oleh siswa dengan sangat antusias.

\section{Saran}

Saran untuk pihak sekolah, bahwa kegiatan pelatihan kesiapsiagaan yang terbaik adalah dengan diberikan kepada seluruh siswa di sekolah ini. Selain itu, seharusnya pada setiap sekolah yang rawan bencana dilengkapi dengan fasilitas seperti petunjuk evakuasi, SOP mengenai penyelamatan diri, dan titik kumpul yang luas. Bagi guru, dapat menyebarluaskan pengetahuan kebencanaan melalui permainan AKSANA pada siswasiswa lainnya. Kegiatan simulasi kebencanaan khususnya gempa bumi seharusnya secara berkala diulangi kembali dalam kurun waktu 3 bulan sekali, sehingga dapat kembali menguatkan memori siswa mengenai kesiapsiagaan bencana.

\section{DAFTAR PUSTAKA}

Beringin, S, P., 2011, Buku panduan menghadapi bencana di sekolah: Sahabat Siaga, UNDP DRR A Project, Hal.1-18.

Hildayani, R., Tarigan, R,S., Pujiati, R., Sugianto, M., Masykouri, A., Handayani, E., 2007, Psikologi Perkembangan Anak, Jakarta: Penerbit Universitas Terbuka, Hal. 4.3-4.17.

Johnson, V, A., Ronan, K,R., Johnston, D,M., Peace, R., 2014, Implementing disaster preparedness education in New Zaeland Primary Schools, Disaster Prevention and Management, Vol. 23 (4) pp. 370-280.

Ormrod, E, J., 2009, Psikologi Pendidikan: Membantu siswa tumbuh dan berkembang, Penerbit Erlangga: Jakarta. Hal. 39-40. 